\title{
The analysis of mercury content in coals and ashes
}

\author{
Marta Kasprzyk ${ }^{1}$, Anna Szpak $^{1, *}$, Iwona Jelonek ${ }^{1}$, and Magdalena Wiktor ${ }^{1}$ \\ ${ }^{1}$ The University of Silesia, Faculty of Earth Sciences, 41-200 Sosnowiec, Będzińska 60 str. , Poland
}

\begin{abstract}
It is well known that mercury that enters the atmosphere is a serious threat to the natural environment. From the available literature, it can be stated that fossil fuels are among the main carriers of this fuel. The question arises whether it is the right approach. While the enrichment of bituminous coal produces limited amounts of mercury, they are being released into the atmosphere as a result of the combustion of coal. The situation is similar in the case of biomass, which releases large amounts of mercury into the atmosphere when subjected to the combustion process. While bituminous coal is the carrier of mercury, the application of currently known technology, rational production and the use of fossil fuels make it possible to maximally minimize mercury emissions into the atmosphere. This study evaluated the mercury content in the ashes resulting from the combustion of bituminous coal subjected to the enrichment process. The samples were collected from ten mines located in the Polish part of the Upper Silesian Coal Basin (USCB). In total, thirty coal samples and thirty products of the combustion process were examined. All sixty samples were subjected to physicochemical analysis, including: moisture content, ash content, sulfur content, carbon content, and Gross Calorific Value.
\end{abstract}

\section{Introduction}

The combustion of coal in both the power sector and private households is related with the emission of mercury compounds into the atmosphere. The reduction of the mentioned emissions is affected by the type of fuel burned, the quality, the type of installation, and the efficiency of flue gas purification systems.

According to the report prepared for the Convention of the United Nations (UN) made by the National Centre for Emissions Balancing and Management (KOBiZE), the Institute of Environmental Protection- National Research Institute, the value of mercury's emission in 2013 increased by $0.18 \%$ compared to 2012 [1]. Estimation of emissions of each air pollutant (Fig.1) was made based on the structure of emission sources included in the Guidance "EEA / EMEP Emission Inventory Guidebook" [2] and the Selected Nomenclature for reporting of Air Pollutants (SNAP). The SNAP 01 sector is among the largest emitters of mercury into the atmosphere $[1,2]$ meaning that the largest amounts of

*Corresponding author: anna.szpak@mixbox.pl 
mercury are emitted as a result of the combustion processes carried out in the production and energy transformation sectors (Fig. 1).

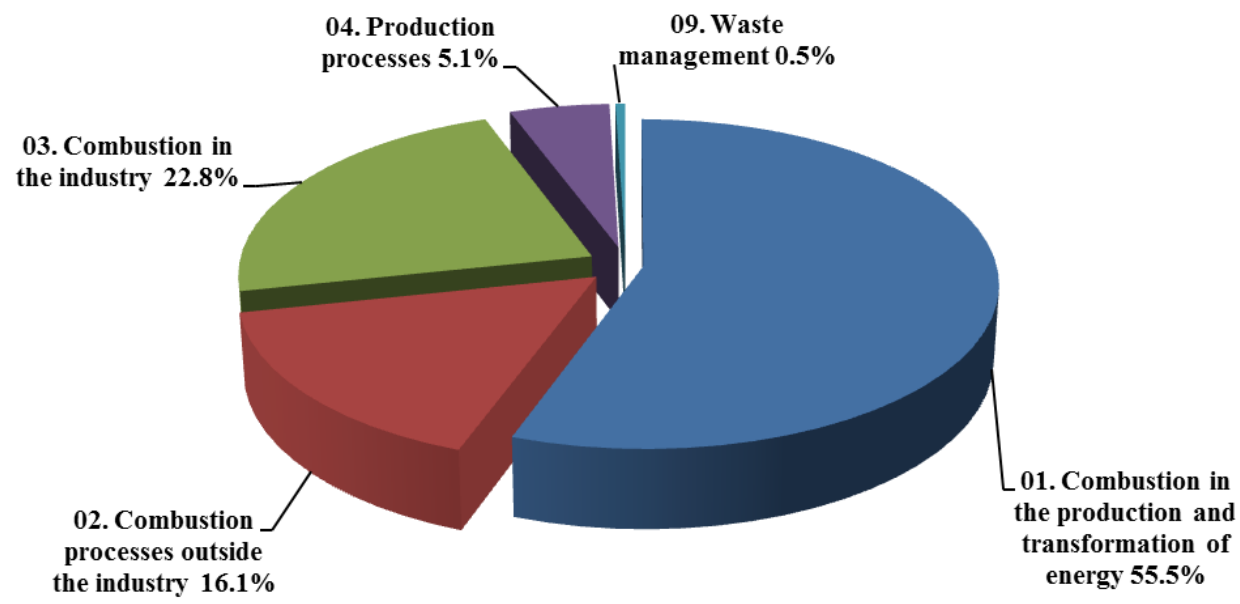

Fig. 1. The share of the largest sectors in mercury emissions in the year 2013 [1].

According to recent studies $[3,8]$, the average mercury content in coals from the Upper Silesian Coal Basin is $0.094 \mu \mathrm{g} / \mathrm{g}$, with a minimum value of $0.020 \mu \mathrm{g} / \mathrm{g}$ and a maximum value of $0.235 \mu \mathrm{g} / \mathrm{g}$. The authors of the mentioned studies pointed out the lack of association between the location of the sample collection and the mercury content [3].

Other studies reported a strong correlation between the sulphur content and the mercury contained in bituminous coal samples [3-8]. Such information is crucial for the preliminary assessment of the quality of coal and its suitability for a given technology.

\section{Samples and analytical procedures}

Bituminous coal samples from 10 mines were analyzed. The commercial samples of coal (i.e. subjected to the enrichment process in order to be used in power industry) were collected from different mines:

- Jastrzębska Spółka Węglowa S.A. (7 mines: Borynia, Jas-Mos, Zofiówka, Budryk, Knurów, Szczygłowice, Pniówek),

- Tauron Wydobycie S.A. (2 mines: Janina, Sobieski);

- Kompania Węglowa S.A. (8 mines: Piast, Ziemowit, Bolesław-Śmiały, Brzeszcze, Chwałowice, Jankowice, Marcel, Rydułtowy-Anna).

A total of 30 samples of bituminous coal, including 7 samples with low sulphur content, 10 with high sulphur content, and 13 mixed with coal slurries, were collected. After their combustion under controlled conditions in a muffle furnace in the laboratory at the Faculty of Earth Sciences of the University of Silesia the ash samples were collected. Coal and ash samples were subjected to a physico-chemical analysis. Samples for further examination were collected and prepared according to the current standards [9].

Each sample was divided into two equal parts, one of which was used to measure moisture content, ash content, sulphur content, carbon content, and Gross Calorific Value, and the other of which was used for the mercury content measurement. The samples of ash were also divided into two equal parts and subjected to ignition loss, sulphur dioxide, and mercury content measurements. All physico-chemical analyses were carried out according to applicable standards [9-15]. 
The measurement of total mercury content for all samples of coal and ash was performed using a Milestone DMA-80 direct mercury analyzer. Calibration of the analyzer was based on patterns provided by the manufacturer (NIST SRM). The analyzes were performed at the Laboratory of Water Analysis, Department of Earth Sciences, the University of Silesia.

\section{Results and discussion}

The results of mercury content and physico-chemical analysis of bituminous coal and ashes after the combustion process are presented in Table 1.

Table 1. Physico-chemical analysis, the mercury content in bituminous coal and ashes.

\begin{tabular}{|c|c|c|c|c|c|c|c|c|c|c|c|c|}
\hline \multicolumn{8}{|c|}{$\mathrm{COAL}$} & \multicolumn{5}{|c|}{$\mathrm{ASH}$} \\
\hline $\begin{array}{c}\text { Sample } \\
\text { No. }\end{array}$ & $\begin{array}{c}\text { Mar } \\
{[\%]}\end{array}$ & $\begin{array}{l}\mathrm{Mad} \\
{[\%]}\end{array}$ & $\begin{array}{l}\text { Aar } \\
{[\%]}\end{array}$ & $\begin{array}{l}\text { Star } \\
{[\%]}\end{array}$ & $\begin{array}{l}\text { Car } \\
{[\%]}\end{array}$ & $\begin{array}{l}\text { Qnet,ar } \\
{[\mathrm{kJ} / \mathrm{kg}]}\end{array}$ & $\begin{array}{c}\mathrm{Hg} \\
{[\mu \mathrm{g} / \mathrm{kg}]}\end{array}$ & $\begin{array}{c}\text { Sample } \\
\text { No. }\end{array}$ & $\begin{array}{c}\text { Ignition } \\
\text { loss } \\
{[\%]}\end{array}$ & $\begin{array}{c}\mathrm{St} \\
{[\%]}\end{array}$ & $\begin{array}{c}\mathrm{Ct} \\
{[\%]}\end{array}$ & $\underset{[\mu \mathrm{gg} / \mathrm{kg}]}{\mathrm{Hg}}$ \\
\hline 1 & 22.2 & 7.5 & 10.2 & 1.27 & 52.4 & 19536 & 776.7 & 31 & 0.8 & 0.41 & 0.7 & 168.3 \\
\hline 2 & 19.8 & 8.4 & 13.3 & 1.37 & 52.3 & 19463 & 742.1 & 32 & 4.4 & 0.29 & 4.1 & 109.6 \\
\hline 3 & 19.5 & 6.4 & 11.8 & 1.21 & \begin{tabular}{|l|}
55.1 \\
\end{tabular} & 20541 & 756.6 & 3 & 2. & 0.27 & 1.9 & 175.3 \\
\hline 4 & 16.5 & 5.5 & 21.9 & 1.10 & 48.7 & 18278 & 457.3 & 34 & 3.1 & 0.20 & 1.7 & 110.4 \\
\hline 5 & 16.4 & 7.4 & 18.8 & 1.10 & 52.8 & 19246 & 431.9 & 35 & 4.2 & 2.18 & 3.4 & 398.3 \\
\hline 6 & 19.9 & 7.1 & 13.1 & 1.19 & 52.6 & 19587 & 532.7 & 36 & 1.6 & 0.25 & 1.3 & 193.5 \\
\hline 7 & 18.6 & 9.0 & 15.4 & 1.12 & 52.0 & 19370 & 546.3 & 37 & 2.5 & 0.24 & 2.0 & 209.6 \\
\hline 8 & 17.6 & 7.0 & 18.1 & 1.10 & 50.8 & 19012 & 469.0 & 38 & 4. & 2.15 & 3.3 & 301.3 \\
\hline 9 & 20.0 & 11.3 & 12.1 & 1.07 & 52.8 & 19451 & 365.9 & 39 & 2.1 & 0.29 & 2.0 & 107.8 \\
\hline 10 & 19.6 & 10.6 & 13.6 & 1.03 & 52.2 & 19443 & 325.7 & 40 & 1.4 & 0.41 & \begin{tabular}{|l|}
0.8 \\
\end{tabular} & 108.7 \\
\hline 11 & 21.0 & 11.4 & 13.1 & 1.03 & 53.1 & 19249 & 313.8 & 41 & 2.4 & 0.23 & 2.1 & 98.6 \\
\hline 12 & 18.5 & 5.0 & 21.2 & 1.02 & 47.9 & 17747 & 301.6 & 42 & 4. & 2.60 & 3.4 & 197.7 \\
\hline 13 & 16.7 & 4.7 & 22.8 & 1.02 & 48.2 & 17796 & 299.3 & 43 & 3.8 & 2.64 & 2.8 & 179.8 \\
\hline 14 & 20.4 & 11.5 & 10.8 & 1.00 & 53.7 & 19775 & 287.4 & 44 & 1.5 & 0.26 & 1.5 & 89.7 \\
\hline 15 & 17.8 & 6.4 & 22.5 & 1.00 & 47.0 & 17409 & 257.3 & 45 & 3. & 2.15 & 3.6 & 156.9 \\
\hline 16 & 17.5 & 5.8 & 22.11 & 1.01 & 47.6 & 17883 & 315.3 & 46 & 3.8 & 2.59 & 3.3 & 261.3 \\
\hline 17 & 18.0 & 5.7 & 16.16 & 0.99 & 53.0 & 19812 & 288.5 & 47 & 5.2 & 2.67 & 4.7 & 212.7 \\
\hline 18 & 17.5 & 6.1 & 23.06 & 1.00 & 47.0 & 17428 & 268.0 & 48 & 3.1 & 3.64 & 2.6 & 147.9 \\
\hline 19 & 16.6 & 5.2 & 21.61 & 0.95 & 49.1 & 18240 & 189.5 & 49 & 3.1 & 2.15 & 2.9 & 102.9 \\
\hline 20 & 18.1 & 7.0 & 18.89 & 0.97 & 50.4 & 18555 & 178.5 & 50 & 3.2 & 2.03 & 3.0 & 100.8 \\
\hline 21 & 17.7 & 5.8 & 20.83 & 0.90 & 49.3 & 18071 & 200.3 & 51 & 3.8 & 2.44 & 3.6 & 96.9 \\
\hline 22 & 19.2 & 3.8 & 19.52 & 0.88 & 48.5 & 17986 & 109.0 & 52 & 3.5 & 2.29 & 3.0 & 61.9 \\
\hline 23 & 17.4 & 5.9 & 10.34 & 0.84 & 59.9 & 22069 & 98.5 & 53 & 9.8 & 0.20 & 8.7 & 12.9 \\
\hline 24 & 14.4 & 4.6 & 23.73 & 0.78 & 50.9 & 18767 & 93.2 & 54 & 1.2 & 0.06 & 1.2 & 1.0 \\
\hline 25 & 11.1 & 4.6 & 24.11 & 0.71 & 52.5 & 19764 & 24.5 & 55 & 0.3 & 0.01 & 0.3 & 1.1 \\
\hline 26 & 11.3 & 3.6 & 26.32 & 0.71 & 50.7 & 18927 & 28.3 & 56 & 1.9 & 0.10 & 1.3 & 1.2 \\
\hline
\end{tabular}




\begin{tabular}{|c|c|c|c|c|c|c|c|c|c|c|c|c|}
\hline 27 & 9.8 & 2.0 & 22.11 & 0.69 & 56.2 & 21307 & 32.1 & 57 & 3.3 & 0.18 & 2.8 & 2.7 \\
\hline 28 & 8.9 & 2.2 & 32.45 & 0.65 & 47.7 & 17809 & 20.1 & 58 & 3.5 & 0.10 & 3.3 & 1.9 \\
\hline 29 & 14.0 & 2.7 & 19.37 & 0.52 & 55.9 & 21003 & 12.5 & 59 & 1.2 & 0.05 & 1.1 & 4.9 \\
\hline 30 & 8.9 & 1.6 & 15.30 & 0.46 & 66.2 & 24918 & 9.5 & 60 & 3.5 & 0.08 & 3.5 & 2.2 \\
\hline
\end{tabular}

Mar - Moisture as received, Mad - Analytical moisture, Aar - Ash content as received, St ar - Total sulphur as received, Car - Carbon as received, Qnet,ar - Net Calorific Value as received, $\mathrm{Hg}$ - Mercury content, $\mathrm{St}$ - Total sulphur content, $\mathrm{Ct}$ - Total carbon content, $\mathrm{Hg}$ - Mercury content.

\subsection{The results of coal analyses}

The maximum sulphur content in 10 coal samples (sample No. 1-10) was in the range from $1.0 \%$ to $1.4 \%$, while the maximum mercury content ranged from $325.7 \mathrm{mg} / \mathrm{kg}$ to $776.7 \mathrm{mg} / \mathrm{kg}$. In the case of ash resulting from the combustion of coal, the mercury content was in the range from $107.8 \mu \mathrm{g} / \mathrm{kg}$ to $398.3 \mu \mathrm{g} / \mathrm{kg}$. When it comes to coal samples (Samples No. 11-13) with the sulfur content from $1.0 \%$ to $0.8 \%$, the mercury content ranges between $315.3 \mu \mathrm{g} / \mathrm{kg}$ and $98.5 \mu \mathrm{g} / \mathrm{kg}$. For the samples which the lowest sulphur content (samples No. 24-30), the mercury content amounted to 9.5-93.2\%. The average mercury content in all 30 samples is $291.0 \mu \mathrm{g} / \mathrm{kg}$.

On the basis of physico-chemical analysis it has been shown that the tested coal is characterized by the following parameters: Total moisture as received is in the range from $8.9 \%$ to $2.2 \%$, Ash content as received ranges from $10.2 \%$ to $32.6 \%$, Total sulphur content is $0.5 \%$ to $1.44 \%$, Carbon as received is $47 \%$ to $66.2 \%$, and the Net Calorific Value as received is ranging between $17409 \mathrm{~kJ} / \mathrm{kg}$ to $24918 \mathrm{~kJ} / \mathrm{kg}$.

\subsection{The results of ash analyses}

In the case of ash produced after the combustion of coal, the mercury content in these samples was highly variable. The highest concentrations of mercury, ranging from $398.34 \mu \mathrm{g} / \mathrm{kg}$ to $107.78 \mu \mathrm{g} / \mathrm{kg}$ were observed in samples of ash produced after the combustion of coal with the highest sulphur and mercury content (samples No. 31-40). In the case of ash samples resulting from the combustion of coal with the average sulphur and mercury content (sample No. 41-53), the mercury content ranges between $261.3 \mu \mathrm{g} / \mathrm{kg}$ and $12.9 \mu \mathrm{g} / \mathrm{kg}$. When it comes to ash produced after the burning of coal with the lowest sulphur and mercury content (samples No. 54-60), the mercury content in all analyzed samples is $120.6 \mu \mathrm{g} / \mathrm{kg}$.

The total sulfur content of ash is the range from $0.01 \%$ to $3.64 \%$, while total carbon content and the ignition loss are the range of $0.3 \%$ to $8.7 \%$ and $0.34 \%$ to $9.8 \%$, respectively.

\subsection{Discussion of the results of statistical analyses}

The correlation between all the parameters presented in Table 1 and the correlation of mercury content in coal and ashes was performed. The standard deviation $\mathrm{R}^{2}$ value, which is a measure of the correlation strength between the variables, is quite strong in the case of coal parameters and amounts to 0.70 (total moisture as received vs. the sulfur content), 0.55 (total moisture as received vs. ash content), and 0.54 (total moisture as received vs. mercury content). A strong correlation between the total sulphur content and the total mercury content, with the standard deviation $\mathrm{R}^{2}$ at 0.92 , has also been observed (Fig. 2). 
Sulphur, \% vs. Mercury, $\mu \mathrm{g} / \mathrm{kg}$

$$
\mathrm{R}^{2}=0.917
$$

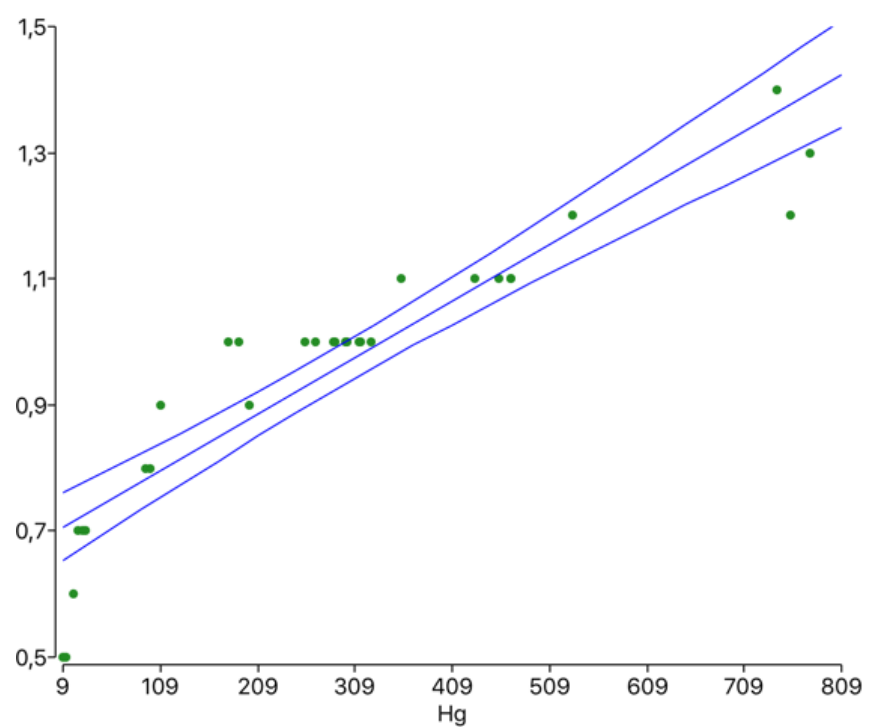

Fig. 2 The correlation between the total sulphur content and the mercury content in bituminous coal samples.

The analyzed correlation between the mercury content in coal and ash is significant, with the standard deviation $\mathrm{R}^{2}$ value amounting to 0.56 (Fig. 3).

$\mathrm{Hg}$ in the coal, $\mu \mathrm{g} / \mathrm{kg} v s . \mathrm{Hg}$ in the ashes, $\mu \mathrm{g} / \mathrm{kg}$

$$
\mathrm{R}^{2}=0.558
$$

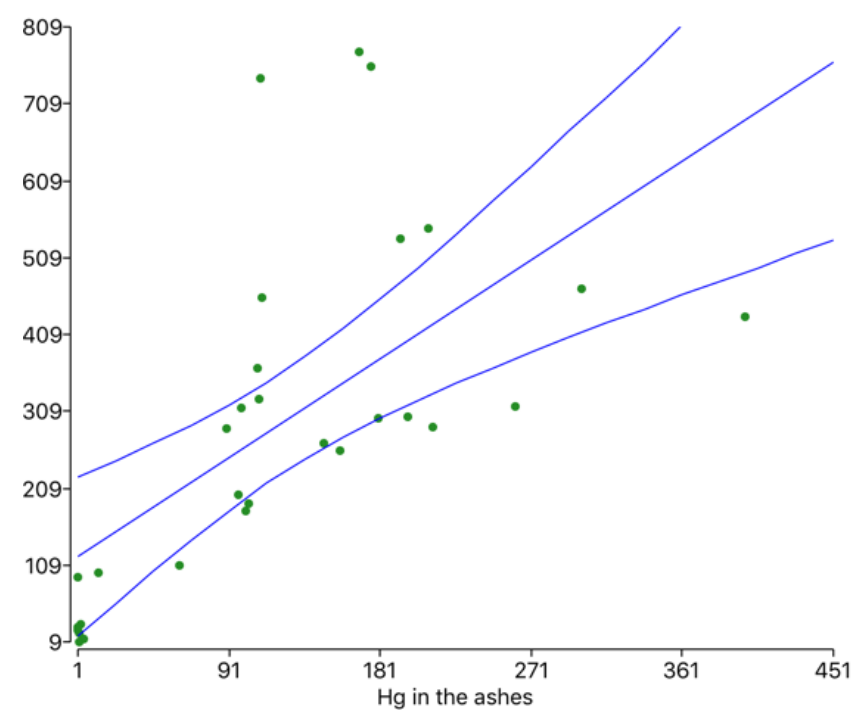

Fig. 3 The correlation between the mercury content present in the examined coal and in the ashes resulting from the combustion of coal.

In contrary, the relationship between the ash and mercury content in the analyzed coal and the mercury content in ash samples is much less pronounced. The coefficient of 
correlation $\mathrm{R}^{2}$ is 0.32 and 0.14 , respectively, while the analysis of variance has shown that the relationship between the variables is weak.

\section{Conclusion}

Based on the results of mercury determination in bituminous coal and furnace wastes, the following conclusions can be drawn:

1. The mercury content in the ash increases with increasing content of total sulfur in coal (Fig. 2).

2. The ash content of the examined coal is not related to the mercury content of coal and ash.

3. The mercury content observed in the coal decreases proportionally to the amount of mercury in ash (Tab. 1).

4. The mercury content in the fuel has a probably impact on mercury emissions and depends on the type of installation used in power plants or individual households.

5. The results have shown a high variability in the mercury content of bituminous coal, which is why a continuous control of this parameter is required.

\section{References}

1. B. Dębski i in., Krajowy bilans emisji $\mathrm{SO}_{2}, \mathrm{NOx}, \mathrm{CO}, \mathrm{NH}_{3}, \mathrm{NMLZO}$, pyłów, metali ciężkich i TZO w układzie klasyfikacji SNAP i NFR. Raport podstawowy, 42 (2015)

2. EMEP/EEA air pollutant emission inventory guidebook 2009 (2013)

3. K. Bojarska, Z. Bzowski, Wiadomości górnicze, 657-662 (2015)

4. K. Wierzchowski, I. Pyka, Górnictwo i Geoinżynieria, 293-302 (2010)

5. B. Toole-O`Neil, S.J. Tewalt, R.B. Finkelman, D.J. Akers, FUEL, 47-54 (1999)

6. M. Wichliński, R. Kobyłecki, Z. Bis, Archives of Environmental Protection, 141-150 (2013)

7. K. Bojarska, MEC3 Third International Expert'sworkshop, 5-7 (2006)

8. T. Dziok, A. Strugała, A. Rozwadowski, M. Macherzyński, FUEL, 206-213 (2015)

9. PN-G-04502:2014-11 Hard and brown coals - Sampling and preparation of samples for the laboratory tests - Primary methods

10. PN-ISO 589:2006P Hard coal - Determination of total moisture

11. PN-ISO 1171:2002P Solid mineral fuels - Determination of ash content

12. PN-ISO 1928:2002P Solid mineral fuels - Determination of gross calorific value by the bomb calorimetric method, and calculation of net calorific value

13. PKN-ISO/TS 12902:2007P Solid mineral fuels - Determination of total carbon, hydrogen and nitrogen - Instrumental methods

14. PN-ISO 351:1999P Solid mineral fuels - Determination of total sulfur - High temperature combustion method

15. PN-EN 15935:2013-02 Sludge, treated biowaste, soil and waste - Determination of loss on ignition 